\title{
Brand Equity and Business Performance in Family and Non-Family Mexican Small Business
}

\author{
Gonzalo Maldonado-Guzman ${ }^{1}$, Sandra Yesenia Pinzón-Castro ${ }^{1} \&$ Dolly Anabel Ortiz-Lazcano ${ }^{2}$ \\ ${ }^{1}$ Centro de Ciencias Económicas y Administrativas, Universidad Autonoma de Aguascalientes, Mexico \\ ${ }^{2}$ MBA Student, Centro de Ciencias Económicas y Administrativas, Universidad Autónoma de Aguascalientes, \\ México \\ Correspondence: Gonzalo Maldonado-Guzman, Centro de Ciencias Económicas y Administrativas, Universidad \\ Autonoma de Aguascalientes, Aguascalientes, Mexico, Avenida Universidad No. 940, Ciudad Universitaria, C.P. \\ 20131, Mexico. E-mail: gmaldona@correo.uaa.mx
}

Received: July 28, 2018

doi:10.5539/ijbm.v13n10p182
Accepted: August 31, 2018

Online Published: September 10, 2018

URL: https://doi.org/10.5539/ijbm.v13n10p182

\begin{abstract}
Brand equity is a topic that has been analyzed and discussed recently by scholars and researchers in the field of marketing. It is also considered as one of the most successful business strategies which allows enterprises, especially small ones, not only to survive in a highly globalized and competitive market bust also to attain a significant increase in their level of business performance. Moreover, the equity of the brand has commonly been studied from the perspective of big enterprises so there are few investigations focused in the analysis of these variables in small companies. This is why the objective of this empirical research is the analysis and discussion of the effects of equity of brand in business performance in small enterprises from a country with an emerging economy, as it is the case of Mexico. The results obtained show that equity brand in products and services of small enterprises have a positive, significant effect in the level of business performance.
\end{abstract}

Keywords: Brand equity, business performance, family firms, small business

\section{Introduction}

Marketing has evolved significantly in the last three decades. A proof of this are the specialized journals and the increased publication of papers regarding this field of knowledge, which usually goes beyond current clients and suppliers of products and services of family and non-family enterprises, including small companies (Frow \& Payne, 2011; Hult et al., 2011; Hult, 2011; Hillebrand et al., 2015). For this reason, the relation between firms and their main partners (e.g. investors, suppliers, distributors, clients, employees and commercial partners), are considered in the current literature as important resources that can help enterprises, including small ones, to improve not only their market ranking but also to increase significantly their level of business performance (Hillebrand et al., 2015; Hui-Ming \& Sengupta, 2016).

Similarly, Vallester and von Wallpach (2013) consider that researchers, academics and professionals in the field of marketing, should pay more attention to the importance of their commercial partners in the co-creation of value for the brand of products or services produced by family and non-family firms, but the research by Hui-Ming and Sengupta (2016) establishes that investigations must focus on the analysis of the relation between brand equity and business performance. However, according to Schultz (2016), there is still a void regarding the meaning of brand equity as there are some investigations that have considered it as the brand equity of consumers (Keller, 1993; Pappu et al., 2005), while other researches have labeled it as brand equity of the market (Amber, 2000; Leone et al., 2006; Frazen \& Moriarty, 2009; Kapferer, 2012).

A possible explanation of this issue can be that probably some researchers or academics ignore or do not have enough knowledge about the importance of the economic and sound value of brand equity in business performance (Kumar \& Hansted-Blomqvist, 2004; Madden et al., 2006; de Chernatony, 2010), especially in family and non-family firms. One of the main reasons for this type of decisions taken by small family and non-family firms, typically the ones located in developing countries or with emerging economies (as it is the case of Mexico), could be that most of the perspectives used in the calculation of the value and equity of the brand is the return of investments (Hui-Ming \& Sengupta, 2016). 
In this regard, the use of the term brand implies that managers of small family and non-family firms will have to carry out the necessary actions to obtain a higher market ranking position, through a better distribution of their products as well as more and better margins of profit and business performance (Hui-Ming \& Sengupta, 2016). This will allow consumers to have a greater perception of additional value and quality of the brand of products and services created by small enterprises (Grewal et al., 1998; Janiszewski \& van Osselaer, 2000). Thus, brands will have an inherent value or equity that will be able to be transferred to the consumers of the products or services of both family and non-family firms through the process of market exchange (Schultz \& Bailey, 2000; Muzellec \& Lambkin, 2006), which could create higher benefits to organizations (Simon \& Sullivan, 1993; Mizik \& Jacobson, 2008), including a better level of business performance (Hui-Ming \& Sengupta, 2016).

In this regard, researchers, academics and professionals in the field of marketing will have to direct their efforts toward theoretical and empirical investigations, that provide sound knowledge of the relation between brand equity and business performance (Davis, 2002; Stahl et al., 2012; Kalb, 2014), especially in small family and non-family firms located in developing countries. Therefore, considering that there are relatively few published papers in the current marketing literature that analyze the relation between brand equity and business performance in small family and non-family firms, the main contribution of this empirical research is the analysis and discussion of the relation between brand equity and business performance, as it is established by Schultz (2016) as well as Hui-Ming and Sengupta (2016).

\section{Method}

In the current literature in the field of marketing it is possible to find some definitions about brand equity which differ among them, and there is no consensus for the use of a specific one (Veloutsou et al., 2013; Davcik et al., 2015). For example, Ailawadi et al. (2003: 1) define brand equity as the "accumulative effects or results of marketing that a specific brand has when compared with the ones obtained by other similar products that have or do not have a brand or name". Thus, some of the few published papers in the current literature have usually focused in the effects of brand equity regarding business performance from the perspective of an enterprise (Hui-Ming \& Sengupta, 2016), especially in small family and non-family firms.

In this regard, the perspective of the enterprise clearly indicates that the creation of brand equity will mostly depend on the results of the level of acquisition of the products and services as well as the perception, attitudes, knowledge and behavior that consumers have with brand equity (Christodoulides \& de Chernatony, 2010). Consequently, most enterprises, especially small family and non-family ones, focus entirely in the attainment of more and better levels of results, such as the price of their products or services, the market fee, the profits and cash flow. All these elements create a higher level of business performance, as well as it allows the survival of this type of enterprises in the market in which they participate.

Similarly, the perspective of brand equity based on the enterprise also contains some important considerations, such as the market of products and the financial markets (Keller \& Lehmann, 2006). The first one practically reflects the performance of brands of the products or services in a market of products, whereas the second one reflects the future ability of brands to obtain benefits and cash flows into the enterprises, especially in small family and non-family firms. Therefore, both considerations are equally important to improve the results obtained from brand equity in the business performance, as well as the very survival of small family and non-family firms.

In comparison to the traditional perspective of brand equity, a more contemporary point of view establishes that the brand equity emerges constantly through the interactions among the departments or areas that integrate the organization, the brands of their products or services and all their commercial partners (Merz et al., 2009; Davcik et al., 2015). Thus, the perspective of cooperation between partners and enterprises through the relation among small family and non-family firms, clients and consumers in the simultaneous creation of brand equity of the products or services of the organizations, binds together the perspective of the enterprise as well as the perspective of consumers.

Some recent published papers in the field of marketing in the current literature that analyze the co-creation of brands, have explored different ways with multiple partners in the co-creation of brand equity (Hui-Ming \& Sengupta, 2016), but the researches that have focused in this type of study are occasional. For example, the meaning of brand and brand equity have provided more and better results, including an significant increase in the level of business performance, when they have been carried out through a simultaneous interaction among enterprises, especially small family and non-family ones, and their main partners (Iglesias \& Bonet, 2012; Vallester \& von Wallpach, 2013).

Moreover, Iglesias et al. (2013) concluded in their research that the partners can co-create brand equity, through 
the conversation and negotiation with enterprises, especially small family and non-family ones, which can provide them a higher level of business performance. Likewise, Gyrd-Jones and Kornum (2013) analyzed in detail the process of the co-creation of brand equity, and they considered important for that the interaction of the main partners of the enterprises in the different activities that brand equity requires as this will allow enterprises, including small family and non-family ones, the joint exploration of new models of representation and expression for brand equity through the improvement or development of new products will allow them to obtain a higher level of business performance.

Similarly, the few published investigations in the marketing literature that analyze brand equity and business performance in small enterprises are the result of three major reasons. The first one is that, usually, researchers only analyze the role of brand equity in the creation of sustainable relations and business performance between small enterprises, mostly small family and non-family ones, and the different partners (Balmer \& Gray, 2003; Schwaiger \& Sarstedt, 2011). The second reason is that the effects of the main partners are more easily observable in the business identity, the image and the reputation of the enterprise, as well as the brand equity (Brown et al., 2006). The third reason is that, from a point of view of management, the decision of designating the resources to the main partners of small enterprises, usually takes place at the level of the equity of the business brand.

However, according to Kozlenkova et al. (2014), when enterprises (including small family and non-family ones), have resources of the brand that are valuable, unique and clearly inimitable, they have higher possibilities to obtain a better brand equity and, consequently, a significant increase in their level of business performance, since brand equity can be in itself a competitive advantage for small enterprises, precisely because the brand of products or services manufactured by the organization create an economic value which is not possible to generate in any other way (Barney, 2014). This facilitates that small family and non-family firms can have a significant increase in their level of business performance.

In this regard, the brands of products or services of small enterprises create equity as one of the most powerful ways to establish sustainable competitive advantages (Hui-Ming \& Sengupta, 2016). Therefore, from a perspective of the resources and capacities that small enterprises have, there are two approaches that can be distinguished about brand equity in the current literature in the field of marketing (Barney, 2001). Firstly, it is possible the competitive advantages that small enterprises have as a result of the actions implemented of brand equity since organizations, often face the actions carried out by other enterprises, which are usually their competitors, when there are activities leading to increase the efficiency and effectiveness of brand equity, which is why small enterprises acquire competitive advantages.

However, the brand equity of goods or services of small family and non-family firms can also show a strategic advantage for the organization regarding the strategies that their main competitors have. This is why it is possible to establish that this approach corresponds practically to a traditional concept of brand equity, which is intrinsically related with the clients and the results of the products or services in the market (Hui-Ming \& Sengupta, 2016). For example, brand equity develops more intensively when consumers react efficiently and effectively to the actions of the brand carried out by small family and non-family enterprises regarding the brand actions implemented by their main competitors (Capon, 2013), which creates a significant increase in the business performance.

Secondly, the competitive advantages that small enterprises have can also be based in the expectations of the economic rent of the investment of shareholders or owners (Barney, 1986, 2001). Thus, enterprises can use the brand of their products or services to create attractive returns of the investment, according to the expectations that investors or owners have from small family and non-family firms, which can create not only more and better competitive advantages but also a higher level of business performance (Hui-Ming \& Sengupta, 2016). This approach corresponds undoubtedly to a concept of brand equity based on financial results, since brand equity is usually considered as the current and futures skills that managers of small enterprises can implement to attract the attention of customers and increase in this way the return of investment from shareholders (Capon, 2013).

Within this set of ideas, the current literature in the field of marketing establishes that brand equity is considered a strong precedent in business performance (Madden et al., 2006; Morgan et al., 2009), and it can also provide different types of competitive advantages such as leadership in the management of the strategy, a unitary cost of manufacture, volume of sales from inventories, delivery, flexibility in the change of volume of orders, and access to labor capital, among others (Saeidi et al., 2015). Thus, if brand equity is improved in small enterprises, whether they are family or non-family owned, it will be more probable to obtain a significant increase in the results of organizations, including a higher level of business performance (Feng et al., 2015). 
Finally, even when it is true that business performance does not only depend on the brand equity of products or services of small enterprises, but also on the factors related to the market and the enterprise in general, the interaction of brand equity with consumers and partners could create a higher level of business performance rather than not carrying out any action (Morgan et al., 2009; Vorhies et al., 2011).

Additionally, the enterprises that achieve the integration of commercial intelligence and information from their main partners, will be able to redesign the resources and processes of the brand equity of the business, as well as to identify and react quickly to the opportunities given by the market for the development of new products, services and processes which will increase the level of business performance (Ayuso et al., 2006; Weerawardena et al., 2006; Olavarrieta \& Friedmann, 2008; Bruni \& Verona, 2009; Ngo \& O’Cass, 2012; Dangelico et al., 2013). Therefore, considering the information presented above, it is possible to establish the following research hypothesis:

\section{H1: The higher the brand equity, the higher the level of business performance}

\subsection{Sampling Procedures}

In order to answer the research hypothesis established in this empirical investigation, it was considered relevant to use the business directory of the Sistema de Información Empresarial Mexicano (System of Mexican Business Information) from Aguascalientes State which had 1,427 registered enterprises, each one containing from 5 to 250 workers at the end of January, 2017. Moreover, an instrument of data collection (i.e. a survey), was designed to be answered specifically by managers or owners of small enterprises. It was carried out as a personal interview with a sample of 300 enterprises selected through a random sampling with a maximum error of $\pm 5 \%$ and a level of reliability of $95 \%$, which represented slightly over $21 \%$ of all the enterprises registered in the business directory. Finally, it is also important to mention that the survey took place between February and April of 2017.

\subsection{Measures and Covariates}

The scale used for the measurement of brand equity was adapted by Berthon et al. (2008) from a scale developed by Keller (2000), who considered that it is possible to measure brand equity through a five-item scale. Additionally, business performance was measured through a three-item scale (1: return of investment, 2: profit compared with the competition, and 3: market participation compared with the competition). This scale was adapted from Tan and Litschert (1994). All the items of both scales were measured through a Likert-type scale of five positions from " $1=$ completely disagree" to " $5=$ completely agree" as limits.

Similarly, a Multiple-group Confirmatory Factorial Analysis (MCFA) was carried out to evaluate the reliability and validity of both scales, by using the method of maximum likelihood with the software EQS 6.2 (Bentler, 2005; Brown, 2006; Byrne, 2006). Furthermore, the reliability was evaluated with Cronbach's alpha as well as the Composite Reliability Index (CRI), proposed by Bagozzi and Yi (1988). The results obtained are shown in Table 1 and show that the theoretical model analyzed has a good adjustment of data $\left(S-B X^{2}=344.707 ; d f=38 ; p\right.$ $=0.000 ; N F I=0.805 ; N N F I=0.835 ; C F I=0.860 ; R M S E A=0.079)$. Likewise, the values of Cronbach's alpha and the CRI are higher than 0.7 , which indicates the presence or reliability in the scales of brand equity and business performance (Nunally \& Bernstein, 1994; Hair et al., 1995).

Furthermore, the results obtained from the FCAM indicate that all the items of the factors related are significant $(\mathrm{p}<0.01)$. The value of all the standardized factorial loads is higher than 0.6 (Bagozzi \& Yi, 1988), and the Extracted Variance Index (EVI) of each pair of constructs of the theoretical model of brand equity and business performance has a value above 0.5 (Fornell \& Larcker, 1981). These values indicate that the theoretical model has a good adjustment of data and provide evidence of the presence of convergent validity. 
Table 1. Internal consistency and convergent validity of the theoretical model

\begin{tabular}{ccccccc}
\hline Variable & Indicator & Factorial Loading & Robust t-Value & Cronbach's Alpha & CRI & EVI \\
\hline & & \multicolumn{2}{c}{ Small Family Business } & & & \\
& BSR1 & $0.823^{* * *}$ & $1.000^{\mathrm{a}}$ & & & \\
& BSR2 & $0.868^{* * *}$ & 22.059 & & & \\
Brand Equity & BSR3 & $0.872^{* * *}$ & 16.955 & 0.903 & 0.904 & 0.655 \\
& BSR4 & $0.761^{* * *}$ & 14.733 & & & \\
& BSR5 & $0.710^{* * *}$ & 15.064 & & & \\
& REN1 & $0.842^{* * *}$ & $1.000^{\mathrm{a}}$ & & & \\
Business Performance & REN2 & $0.964^{* * *}$ & 14.418 & 0.878 & 0.879 & 0.710 \\
& REN3 & $0.702^{* * *}$ & 10.753 & & & \\
& & Small Non-Family Business & & & \\
& BSR1 & $0.931^{* * *}$ & $1.000^{\mathrm{a}}$ & & & \\
& BSR2 & $0.975^{* * *}$ & 22.765 & & & \\
Brand Equity & BSR3 & $0.877^{* * *}$ & 14.099 & 0.915 & 0.916 & 0.690 \\
& BSR4 & $0.674^{* * *}$ & 8.460 & & & \\
& BSR5 & $0.641^{* * *}$ & 9.047 & & & \\
& REN1 & $0.795^{* * *}$ & $1.000^{\mathrm{a}}$ & & & \\
Business Performance & REN2 & $0.990^{* * *}$ & 8.380 & 0.863 & 0.864 & 0.686 \\
& REN3 & $0.667^{* * *}$ & 6.462 & & & \\
\hline
\end{tabular}

$S-B X^{2}(\mathrm{df}=38)=344.707 ; \mathrm{p}<0.000 ; \mathrm{NFI}=0.805 ; \mathrm{NNFI}=0.835 ; \mathrm{CFI}=0.860 ; \mathrm{RMSEA}=0.079$.

${ }^{\mathrm{a}}=$ Constrained parameters to such value in the identification process.

$* * * \mathrm{p}<0.01$.

Similarly, the discriminant validity of the theoretical model of brand equity and business performance was measured through the reliability interval test (Anderson \& Gerbing, 1988), which establishes that with an interval of $95 \%$ of reliability none of the individual elements of the latent factors of the matrix of correlation must have a value of 1.0. Therefore, based on the results obtained from the test applied, it can be concluded that there is enough evidence of the presence of discriminant validity.

Table 2. Discriminant validity of the theoretical model

\begin{tabular}{cccc}
\hline Variables & \multicolumn{2}{c}{ Brand Equity } & Business Performance \\
\hline $\begin{array}{c}\text { Brand Equity } \\
\text { Business Performance }\end{array}$ & $0.102-0.478$ & $0.139-0.399$ \\
\hline
\end{tabular}

Above the diagonal the estimated correlation of factors is presented with $95 \%$ confidence interval of the Family SMEs. Below diagonal, the estimated correlation of factors is presented with $95 \%$ confidence interval of the Non-Family SMEs.

\section{Results}

In order to answer the research hypothesis established in this empirical research, a multi-group structural equations model was applied with software EQS 6.2 (Bentler, 2005; Byrne, 2006; Brown, 2006). Likewise, the nomological validity of the theoretical model of brand equity and business performance was examined through the Chi-square test, which compared the results obtained between the theoretical model and the measurement model. Such results indicate that the differences between both models are not significant, which can offer an explanation of the relationships observed among the latent constructs (Anderson \& Gerbing, 1988; Hatcher, 1994). Table 3 shows the results in a more detailed way regarding the implementation of the model multi-group structural equations model. 
Table 3. Results of the structural equation model of second-order

\begin{tabular}{|c|c|c|c|}
\hline Hypothesis & Structural Relationship & $\begin{array}{l}\text { Standardized } \\
\text { Coefficient }\end{array}$ & $\begin{array}{l}\text { Robust } \\
\text { t-Value }\end{array}$ \\
\hline \multicolumn{4}{|l|}{ Small Family Business } \\
\hline $\begin{array}{l}\text { H1: The higher level of brand equity, higher level of business } \\
\text { performance. }\end{array}$ & $\begin{array}{l}\text { Brand Equity } \\
\text { Business P. }\end{array}$ & $0.328 * * *$ & 4.363 \\
\hline \multicolumn{4}{|l|}{ Small Non-Family Business } \\
\hline $\begin{array}{l}\text { H1: The higher level of brand equity, higher level of business } \\
\text { performance. }\end{array}$ & $\begin{array}{l}\text { Brand Equity } \quad \rightarrow \\
\text { Business P. }\end{array}$ & $0.327 * * *$ & 3.160 \\
\hline \multicolumn{4}{|c|}{$S-B X^{2}(\mathrm{df}=38)=344.796 ; \mathrm{p}<0.000 ; \mathrm{NFI}=0.805 ; \mathrm{NNFI}=0.835 ; \mathrm{CFI}=0.860 ; \mathrm{RMSEA}=0.079$} \\
\hline
\end{tabular}

Table 3 shows the results obtained from the multi-group structural equations model and it can be observed that the results of the research hypothesis $\mathbf{H}_{1}(\beta=0.328, \mathrm{p}<0.01)$ of small family firms, indicate that brand equity has significant, positive effects in the business performance. Moreover, the results obtained regarding the research hypothesis $\mathbf{H}_{1}(\beta=0.327, \mathrm{p}<0.01)$ of small non-family firms, indicate that brand equity also has significant, positive effects in the business performance. Therefore, it is possible to establish that the different activities of brand equity adopted and implemented by small family and non-family firms have a positive and significant effect in their level of business performance.

\section{Discussion}

The results obtained in this empirical research allow us to conclude in three main aspects. Firstly, brand equity activities regarding the products or services created by small enterprises, whether they are family or non-family, are essential not only for the attainment of more and better results but also for the very survival of small enterprises. Consequently, it is possible to conclude that the brand equity of products and services from small family and non-family firms, must be considered by different researchers and academics in the current marketing literature, as one of the most successful business strategies nowadays which is being used by an increasing number of small enterprises in order to stay in the market where they participate as well as to obtain better business performance.

Secondly, it is possible to state that most, if not all, small family and non-family firms have as a main goal to attain a significant increase in their level of business performance. Thus, in order to achieve this objective, it will be necessary to adapt or modify their current business strategies or produce new ones such as brand equity. As a result of this, it is possible to conclude that brand equity is one of the business strategies that can be used for both small family and non-family firms, in order to get better results including a higher level of business performance, since brand equity can be easily adapted to the organizational structure of small enterprises without making big changes in the organization.

Thirdly, it is possible to conclude in a general way that brand equity activities carried out by both small family and non-family firms, have positive, significant effects in their level of business performance. Consequently, if small enterprises have as one of their main goals to increase their level of business performance, then first they will have to adopt and implement activities that imply brand equity, because it is precisely this type of activities that facilitate the attainment of more and better results in the organization, such as the level of business performance and a better market position in which they participate regardless if it is a small family or non-family firms.

Furthermore, the results obtained in this empirical research have several implications that are important to mention. It is possible to establish as the first implication that, in general, most small family or non-family firms in developing countries, as it is the case of Mexico, do not copyright the commercial brand of their products or services and consequently some brand equity activities can become very difficult. That is why managers and/or owners of small family or non-family firms, will have to make an effort, besides copyrighting the brand of their products or services, in order to adopt and implement all the activities that imply and effective and efficient brand equity of their products or services, which will provide the enterprises with a better market ranking in all the line of their products or services. 
A second implication obtained from these results is that both small family and non-family firms, have to consider that brand equity not only as another business strategy of the organization, but rather as a series of activities that must be implemented every day so they become an essential part of the organization. Therefore, it will be necessary that managers and/or owners of enterprises involve all the areas or departments that are part of the organization so small family and non-family firms can achieve an efficient and effective brand equity of their line of products or services.

A third implication of the results obtained is that managers and/or owners of small family and non-family firms, will have to involve all their employees and workers in the different activities of brand equity regarding their line of products and services. This is mostly because the personnel of the organization are the one that will be in direct contact with clients and consumers of the products or services produced by the enterprise. If they do not have in mind the importance of brand equity, then it will be too complicated for them to provide a good image and information about the products or services of the organization. This could create not only a significant decrease in the level of business performance of small family and non-family firms, but also a reduction in their possibilities to survive in the market where they participate.

A fourth implication of the results obtained is that managers and/or owners of small family and non-family firms, will have to implement training programs for their employees and workers so they have the necessary tools, knowledge and skills to make more efficient and effective the brand equity of the products or services of the organization. It is also possible to take advantage of the different training programs offered by business associations, international organizations or any of the three levels of government branches regarding brand equity and intellectual copyright. This training will allow small family and non-family firms to have higher possibilities to increase significantly their level of business performance and their market position.

Additionally, this empirical research has some limitations that are necessary to mention. The first one is about the sample used as only small family and non-family firms that had between 5 and 250 workers were considered. That is why future investigations will have to consider small family and non-family firms with less than five workers in order to confirm the results obtained. The second limitation is that the questionnaire applied to collect the data only considered small family and non-family firms in the state of Aguascalientes (Mexico), even when small enterprises have similar characteristics in all the country. Future researches will need to apply the questionnaire in other states of the country and even other countries in order to verify if the results obtained are similar.

A third limitation is the scale used to measure both brand equity and business performance of small family and non-family firms, as it used only five items to measure brand equity and three items to measure business performance. The following investigations will need to use a different scale for the measurement of both variables to confirm the results obtained. A fourth limitation is that only qualitative variables were considered to measure both brand equity and business performance, so in future investigations it will be necessary to consider hard data or quantitative variables to prove the presence or lack of any significant differences in the results of brand equity in business performance.

A fifth limitation is that the instrument applied to collect data only considered managers and/or owners of small family and non-family firms. This created the assumption in the research paper that they have a deep understanding about brand equity and business performance of their enterprises. Future research papers will need to apply the same questionnaire to employees and workers of small family and non-family firms, in order to confirm the results obtained. Finally, the last limitation is that a high percentage of small family and non-family firms, considered that the information requested was confidential so the results obtained do not necessarily reflect the reality that this type of enterprises have regarding the brand equity and business performance of enterprises.

\section{References}

Ailawadi, K.L., Lehmann, D.R., \& Neslin, S.A. (2003). Revenue premium as an outcome measure of brand equity. Journal of Marketing, 67(4), 1-17. http://dx.doi.org/10.1509/jmkg.67.4.1.18688

Ambler, T. (2000). Marketing metrics. Business Strategy Review, 11(2), 59-66. http://dx.doi.org/10.1111/1467-8616.00138

Anderson, J., \& Gerbing, D. (1988). Structural equation modeling in practice: a review and recommended two-step approach. Psychological Bulletin, 13, 411-423.

Ayuso, S., Rodríguez, M.A., \& Ricart, J.E. (2006). Using stakeholder dialogue as a source for new ideas: A dynamic capabilities underlying sustainable innovation. Corporate Governance, 6(4), 475-490. 
http://dx.doi.org/10.1108/14720700610689586

Bagozzi, R.P., \& Yi, Y. (1988). On the evaluation of structural equation models. Journal of the Academy of Marketing Science, 16(1), 74-94. http://dx.doi.org/10.1007/BF02723327

Balmer, J. M. T., \& Gray, E. R. (2003). Corporate brands: What are they? What of them? European Journal of Marketing, 37(7/8), 972-997. http://dx.doi.org/10.1108/03090560310477627

Barney, J.B. (1986). Strategic factor markets: Expectations, luck, and business strategy. Management Science, $32(2), 1512-1514$.

Barney, J.B. (2001). Is the resource-based view a useful perspective for strategic management research? Yes. Academy of Management Review, 26(1), 41-56. http://dx.doi.org/10.2307/259393

Barney, J.B. (2014). How marketing scholars might help address issues in resource-based theory. Journal of the Academy of Marketing Science, 42(1), 24-26. http://dx.doi.org/10.1007/s11747-013-0351-8

Barrales-Molina, V., Martínez-López, F. J., \& Vazquez-Abad, J.C. (2014). Dynamic marketing capabilities: Toward an integrative framework. International Journal of Management Review, 16(4), 397-416.

Bentler, P. (2005). EQS 6 Structural Equations Program Manual. Encino, CA: Multivariate Software.

Brown, T. (2006). Confirmatory Factor Analysis for Applied Research. New York, NY: The Guilford Press.

Brown, T., Dacin, P., Pratt, M. G., \& Whetten, D. A. (2006). Identity, intended image, construed image, and reputation: An interdisciplinary framework and suggested terminology. Journal of the Academy of Marketing Science, 34(2), 99-106. http://dx.doi.org/10.1177/0092070305284969

Bruni, D. S., \& Verona, G. (2009). Dynamic marketing capabilities in science-based firms: An exploratory investigation of the pharmaceutical industry. British Journal of Management, 20(1), 101-117.

Byrne, B. (2006). Structural Equation Modeling With EQS, Basic Concepts, Applications, and Programming (2nd ed.). London; LEA Publishers.

Capon, N. (2013). Capon's Marketing Framework. (3rd ed.). Bronxville, NY: Wessex publishing.

Christodoulides, G., \& De Chernatony, L. (2010). Consumer-based brand equity conceptualization and measurement: A literature review. International Journal of Research in Marketing, 52(1), 43-66.

Dangelico, R. M., Pontrandolfo, P., \& Pujari, D. (2013). Developing sustainable new products in the textile and upholstered furniture industries: Role of external integrative capabilities. Journal of Product Innovation Management, 30(4), 642-658. http://dx.doi.org/10.1111/jpim.12013

Davcik, N. S., Da Silva, R. V., \& Hair, J. (2015). Towards a unified theory of brand equity: Conceptualizations, taxonomy and avenues for future research. Journal of Product \& Brand Management, 24(1), 3-17. http://dx.doi.org/10.1108/JPBM-06-2014-0639

Davis, S. (2002). Brand asset management: How businesses can profit from the power of brand. Journal of Consumer Marketing, 19(4), 351-358. http://dx.doi.org/10.1108/07363760210433654

de Chernatony, L. (2010). From Brand Vision to Brand Evaluation: The Strategic Process of Growing and Strengthening Brands. London: Routledge.

Feng, H., Morgan, N. A., \& Rego, L. L. (2015). Marketing department power and firm performance. Journal of Marketing, 79(5), 1-20. http://dx.doi.org/10.1509/jm.13.0522

Fornell, C., \& Larcker, D. (1981). Evaluating structural equation models with unobservable variables and measurement error. Journal of Marketing Research, 18(1), 39-50. http://dx.doi.org/10.2307/3151312

Frazen, G., \& Moriarty, S. (2009). The Science and Art of Branding. Armonk, NY: ME Sharpe.

Frow, P., \& Payne, A. (2011). A stakeholder perspective of the value proposition concept. European Journal of Marketing, 45(1/2), 223-240. http://dx.doi.org/10.1108/03090561111095676

Grewal, D., Krishnan, R., Baker, J., \& Borin, N. (1998). The effect of store name, brand name and price discounts on consumers' evaluations and purchase intentions. Journal of Retailing, 74(3), 331-352. http://dx.doi.org/10.1016/S0022-4359(99)80099-2

Gyrd-Jones, R.I., \& Kornum, N. (2013). Managing the co-created brand: Value and cultural complementarity in online and offline multi-stakeholder ecosystems. Journal of Business Research, 66(9), 1484-1493. http://dx.doi.org/10.1016/j.jbusres.2012.02.045 
Hair, J. F., Anderson, R. E., Tatham, R. L., \& Black, W. C. (1995). Multivariate data analysis with readings. New York, NY: Prentice-Hall.

Hatcher, L. (1994). A Step by Step Approach to Using the SAS System for Factor Analysis and Structural Equation Modeling. Cary, NC: SAS Institute Inc.

Hillebrand, B., Driessen, P. H., \& Koll, O. (2015). Stakeholder marketing: Theoretical foundations and required capabilities. Journal of the Academy of Marketing Science, 43(4), 411-428. http://dx.doi.org/10.1007/s11747-015-0424-y

Hui-Ming, D. W., \& Sengupta, S. (2016). Stakeholder relationships, brand equity, firm performance: A resource-based perspective. Journal of Business Research, 69(1), 5561-5568.

Hult, G. T. M. (2011). Toward a theory of the boundary-spanning marketing organization and insights from 31 organization theories. Journal of the Academy of Marketing Science, 39(4), 509-536. http://dx.doi.org/10.1007/s11747-011-0253-6

Hult, G. T. M., Mena, J. A., Farrell, O. C., \& Farrell, L. (2011). Stakeholder marketing: A definition and conceptual framework. AMS Review, 1(1), 44-65. http://dx.doi.org/10.1007/s13162-011-0002-5

Iglesias, O., \& Bonet, E. (2012). Persuasive brand management: How managers can influence brand meaning when they are losing control over it. Journal of Organizational Change Management, 25(2), 251-264. http://dx.doi.org/10.1108/09534811211213937

Iglesias, O., Ind, N., \& Alfaro, M. (2013). The organic view of the brand: A brand value co-creation model. Journal of Brand Management, 20(8), 670-688. http://dx.doi.org/10.1057/bm.2013.8

Janiszewski, C., \& van Osselaer, S. M. (2000). A connectionist model of brand - quality associations. Journal of Marketing Research, 37(3), 331-350. http://dx.doi.org/10.1509/jmkr.37.3.331.18780

Kalb, M. (2014). Business Insider: Why great branding can make you more money. Retrieved from http://www.businessinsider.com/heres-how-great-branding-strategies-give-you-control-over-price-and-distri bution-2014-2

Kapferer, J. N. (2012). The New Strategic Brand Management: Advances Insights and Strategic Thinking. London: Kogan Page Publishers.

Keller, K. L. (1993). Conceptualizing, measuring, and managing customer-based brand equity. Journal of Marketing, 1(1), 1-12.

Keller, K. L., \& Lehmann, D. (2006). Brands and branding: Research findings and future priorities. Marketing Science, 25(6), 740-759. http://dx.doi.org/10.1287/mksc.1050.0153

Kozlenkova, I. V., Samaha, S. A., \& Palmatier, R. W. (2014). Resource-based theory in marketing. Journal of the Academy of Marketing Science, 42(1), 1-21. http://dx.doi.org/10.1007/s11747-013-0336-7

Kumar, S., \& Hansted-Blomqvist, K. (2004). Making brand equity a key factor in M\&A decision-making. Strategy \& Leadership, 32(2), 20-27. http://dx.doi.org/10.1108/10878570410525098

Leone, R. P., Rao, V. R., Keller, K. L., Luo, A. M., McAlister, L., \& Srivastava, R. (2006). Linking brand equity to customer equity. Journal of Service Research, 9(2), 125-138. http://dx.doi.org/10.1177/1094670506293563

Madden, T. J., Fehle, F., \& Fournier, S. M. (2006). Brands matter: An empirical demonstration of the creation of the shareholder value through branding. Journal of the Academy of Marketing Science, 34(2), 224-235. http://dx.doi.org/10.1177/0092070305283356

Merz, M. A., He, Y., \& Vargo, S. L. (2009). The evolving brand logic: A service-dominant logic perspective. Journal of the Academy of Marketing Science, 37(3), 328-344. http://dx.doi.org/10.1007/s11747-009-0143-3

Mizik, N., \& Jacobson, R. (2008). The financial value impact of perceptual brand attributes. Journal of Marketing Research, 44(1), 15-32.

Morgan, N. A., Slotegraaf, R. J., \& Vorhies, D. W. (2009). Linking marketing capabilities with profit growth. International Journal of Research in Marketing, 26(4), 284-293. http://dx.doi.org/10.1016/j.ijresmar.2009.06.005

Muzellec, L., \& Lambkin, M. (2006). Corporate rebranding: Destroying, transferring or creating brand equity? European Journal of Marketing, 40(7/8), 803-824. http://dx.doi.org/10.1108/03090560610670007 
Ngo, L. V., \& O’Cass, A. (2012). In search on innovation and customer-related performance superiority: The role of marketing orientation, marketing capability, and innovation capability interactions. Journal of Product Innovation Management, 29(5), 861-877. http://dx.doi.org/10.1111/j.1540-5885.2012.00939.x

Nguyen, T. D., Dadzie, C., Davari, A., \& Guzman, F. (2015). Intellectual capital through the eyes of the consumer. Journal of Product \& Brand Management, 24(6), 554-566. http://dx.doi.org/10.1108/JPBM-03-2015-0837

Nunally, J. C., \& Bernstein, I. H. (1994). Psychometric Theory (3rd ed.). New York, NY: McGraw-Hill.

Olavarrieta, S., \& Friedmann, R. (2008). Market orientation, knowledge-related resources and firm performance. Journal of Business Research, 61(6), 623-630. http://dx.doi.org/10.1016/j.jbusres.2007.06.037

Pappu, R., Quester, P. G., \& Cooksey, R. W. (2005). Consumer-based brand equity: Improving the measurement-empirical evidence. Journal of Product \& Brand Management, 14(3), 143-154. http://dx.doi.org/10.1108/10610420510601012

Saeidi, S. P., Sofian, S., Saeidi, P., Saeidi, S. P., \& Saeidi, S. A. (2015). How does corporate social responsibility contribute to firm financial performance? The mediating role of competitive advantage, reputation, and customer satisfaction. Journal of Business Research, 68(2), 341-350. http://dx.doi.org/10.1016/j.jbusres.2014.06.024

Schultz, D. (2016). Market brand equity: Lost in terminology and techniques? Journal of Product \& Brand Management, 25(6), 507-515. http://dx.doi.org/10.1108/JPBM-07-2016-1260

Schultz, D. E., \& Bailey, S. E. (2000). Customer/brand loyalty an in interactive marketplace. Journal of Advertising Research, 40(3), 41-52. http://dx.doi.org/10.2501/JAR-40-3-41-52

Schwaiger, M., \& Sarstedt, M. (2011). Corporate branding in a turbulent environment. Journal of Brand Management, 19(3), 179-181. http://dx.doi.org/10.1057/bm.2011.35

Simon, C.J., \& Sullivan, M.W. (1993). The measurement and determinants of brand equity: A financial approach. Marketing Science, 12(1), 28-52. http://dx.doi.org/10.1287/mksc.12.1.28

Stahl, F., Heitmann, M., Lehmann, D.R., \& Neslin, S.A. (2012). The impact of brand equity on customer acquisition, retention, and profit margin. Journal of Marketing, 76(4), 44-63. http://dx.doi.org/10.1509/jm.10.0522

Vallester, C., \& Von Wallpach, S. (2013). An online discursive inquiry into the social dynamics of multiple-stakeholder brand meaning co-creation. Journal of Business Research, 66(9), 1505-1515.

Veloutsou, C., Christodoulides, G., de Chenatony, L. (2013). A taxonomy of measures for consumer-based brand equity: Drawing on the views of managers in Europe. Journal of Product \& Brand Management, 22(3), 238-248. http://dx.doi.org/10.1108/JPBM-02-2013-0256

Vorhies, D.W., Orr, L.M., \& Bush, V.D. (2011). Improving customer-focused marketing capabilities and firm financial performance via marketing exploration and exploitation. Journal of the Academy of Marketing Science, 39(5), 736-756. http://dx.doi.org/10.1007/s11747-010-0228-z

Weerawardena, J., O’Cass, A., \& Julian, C. (2006). Does industry matter? Examining the role of industry structure and organizational learning in innovation and brand performance. Journal of Business Research, 59(1), 37-45. http://dx.doi.org/10.1016/j.jbusres.2005.02.004

\section{Copyrights}

Copyright for this article is retained by the author(s), with first publication rights granted to the journal.

This is an open-access article distributed under the terms and conditions of the Creative Commons Attribution license (http://creativecommons.org/licenses/by/4.0/). 